\title{
Combined Effects of Induced Water Deficit and Foliar Application of Silicon on the Gas Exchange of Tomatoes for Processing
}

\author{
Diogo Henrique Morato de Moraes ${ }^{1}\left(\mathbb{D}\right.$, Marcio Mesquita ${ }^{1, *} \mathbb{C}$, Amanda Magalhães Bueno ${ }^{1}$, \\ Rilner Alves Flores ${ }^{1}\left(\mathbb{D}\right.$, Henrique Fonseca Elias de Oliveira ${ }^{2}$, \\ Frederico Simões Raimundo de Lima ${ }^{1}$, Renato de Mello Prado ${ }^{3}$ (D) and Rafael Battisti ${ }^{1}$ (D) \\ 1 Postgraduate Program in Agronomy, Federal University of Goiás, Esperança Avenue, \\ Goiânia 74690-900, Brazil; diogo.slmb@gmail.com (D.H.M.d.M.); amanda.mabu@gmail.com (A.M.B.); \\ rilner@ufg.br (R.A.F.); fredlimaufg@yahoo.com.br (F.S.R.d.L.); battisti@ufg.br (R.B.) \\ 2 Cerrado Irrigation Postgraduate Program, Goiano Federal Institute, GO-154, Km 03, Ceres 76300-000, Brazil; \\ henrique.fonseca@ifgoiano.edu.br \\ 3 Faculty of Agricultural and Veterinary Sciences, São Paulo State University "Júlio de Mesquita Filho", \\ Jaboticabal, Access way Prof. Paulo Donato Castellane, 000, Jaboticabal 14884-900, Brazil; \\ rm.prado@unesp.br \\ * Correspondence: marciomesquita@ufg.br; Tel.: +55-(62)-3521-2376
}

Received: 29 September 2020; Accepted: 3 November 2020; Published: 5 November 2020

\begin{abstract}
The beneficial effects of silicon (Si) on plants have been widely reported for its fruit qualitative improvements, growth gains, and protection against abiotic and biotic stresses. This study aimed to evaluate the combined effect of soil water potential ( $\Psi \mathrm{s})(-30$ and $-60 \mathrm{kPa})$ and the foliar application of Si (0.0 (control), 1.0, 2.0, 3.0, and $\left.4.0 \mathrm{~g} \mathrm{~L}^{-1}\right)$ in the development of tomatoes grown in a greenhouse. We evaluated the biometric parameters and gas exchange in three periods $(20,34$, and 48 days after planting). The rates of transpiration $(E)$, stomatal conductance ( $g s)$, and net photosynthesis assimilation $\left(A_{n}\right)$ were lower when the plants were subjected to water deficit. The foliar application of $\mathrm{Si}$ attenuated the effect of the water deficit in both levels applied to the crop. A high response was observed at $-60 \mathrm{kPa}$, regardless of the evaluated period. However, a significant effect was not observed on the relative chlorophyll index and biomass accumulation when Si was applied. A foliar application up to $2.8 \mathrm{~g} \mathrm{~L}^{-1}$ promotes increases in $A_{n}, g S$, and $E$. It is highlighted that $\mathrm{Si}$ can promote improvements in gas exchange when plants are affected by a water deficit.
\end{abstract}

Keywords: Solanum lycopersicum L.; growth; silicon application method; water-plant relationship

\section{Introduction}

Hydro-climatic conditions affect plants by decreasing the net assimilation rate of photosynthesis $\left(A_{n}\right)$, stomatal conductance $(g s)$, transpiration rate $(E)$, internal $\mathrm{CO}_{2}$ concentration $(C i)$, and, consequently, the yield and fruit quality. In several crops, for example, eggplant (Solanum melongena L.), soybean (Glycine max L.), grapevine (Vitis vinifera L.), and wheat (Triticum turgidum), gas exchange parameters respond to the soil water potential ( $\Psi$ s) [1-3].

Patane et al. studied the yield of tomato varieties in response to a prolonged water deficit in the soil [4], founding that some of cultivars had values of leaf transpiration and proline that indicate a high tolerance to drought, thus being suitable for cultivation in semi-arid regions. Mesquita et al. reduced the total amount of water applied during the tomato cycle by applying water deficit levels without affecting yields [5]. The content of soluble solids increases in tomato fruits under water deficit, maintaining the titratable acidity and improving its quality for industrial processing. Several studies report the 
effect of soil water status on tomato productivity, but few relate their effect on gas exchange [6,7]. Thus, it is important to use strategies to improve the use and application of water in crops, considering gas exchange.

The use of silicon $(\mathrm{Si})$ has shown positive results in agriculture to relieve abiotic stresses inherent to the plant, including water deficits [8,9]. Si helps to reduce water stress; this is attributed to its polymerization after absorption and deposition in the cell walls of roots, stems, and leaves, forming a double layer of silica-cuticle and silica-cellulose $[10,11]$. Thus, there is an increase in the resistance and hardness of the cell walls, reducing transpiration and increasing the activity of peroxidase, an enzyme related to the plant's defense mechanisms [11-13]. In field conditions, Si promoted a higher tolerance to dehydration and loss of turgor through maintenance of the water content in cells, increasing the photosynthetic performance and allowing improvement in water-use efficiency [14,15].

The reports in the literature regarding the physiological mechanisms of the response to water availability in tomatoes are still quite limited; therefore, because the physiological and development aspects of the plant are closely related to the variation in the water content in the soil, with direct influence on production, the importance of understanding this set of factors in tomato cultivation becomes evident. We believe that the foliar application of Si controls stomatal conduction and mitigate the effects of a water deficit in tomato plants. This study therefore aims to evaluate the effect of the foliar application of $\mathrm{Si}$ on the water-use efficiency of tomatoes under different water potentials in the soil ( $\Psi$ s), under greenhouse conditions.

\section{Materials and Methods}

A hybrid cultivar of tomato, Nunhems 901 (N-901), was grown in a greenhouse in the municipality of Goiânia, Goiás, Brazil $\left(16^{\circ} 35^{\prime} \mathrm{N}, 49^{\circ} 21^{\prime} \mathrm{W}\right.$; altitude, $724 \mathrm{~m}$ a.s.l.). Air temperature (minimum and maximum) and relative air humidity (\%) were monitored. The region has a tropical savanna climate with dry winters and rainy summers (Aw), according to Köppen climate classification [16].

The experiment was randomized blocks with treatments arranged in a $5 \times 2$ factorial design, corresponding to five doses of Si: 0.0 (control), 1.0, 2.0, 3.0, and $4.0 \mathrm{~g} \mathrm{~L}^{-1}$, and two soil water potentials $(\Psi \mathrm{s}):-30$ and $-60 \mathrm{kPa}$, with four repetitions. The water potential values were used following the recommendation of Mesquita et al. [5], who observed no difference yield when using $-60 \mathrm{kPa}$ to $-30 \mathrm{kPa}$.

The experimental unit consisted of a 12-L pot filled with soil samples with the following fertility attributes: $\mathrm{pH}=5.7, \mathrm{P}=113.1 \mathrm{mg} \mathrm{dm}^{-3}, \mathrm{H}+\mathrm{Al}=13 \mathrm{cmol}_{\mathrm{C}} \mathrm{dm}^{-3}, \mathrm{~K}=900 \mathrm{mg} \mathrm{dm}^{-3}, \mathrm{Ca}=802 \mathrm{mg} \mathrm{dm}^{-3}$, $\mathrm{Mg}=158 \mathrm{mg} \mathrm{dm}^{-3}$, organic matter $=17.0 \mathrm{~g} \mathrm{~kg}^{-1}$, and cation exchange capacity $(\mathrm{CEC})=9.0 \mathrm{cmol}_{\mathrm{C}} \mathrm{kg}^{-1}$; and the following physical attributes: sand $=46 \%$, silt $=20 \%$, and clay $34 \%$. We carefully mixed the entire volume of the soil before allocation to the experimental units.

Leaf sprays were applied with stabilized alkaline silicate, containing $\mathrm{Si}=107 \mathrm{~g} \mathrm{~L}^{-1}(3.81 \mathrm{M})$, $\mathrm{K}_{2} \mathrm{O}=28.4 \mathrm{~g} \mathrm{~L}^{-1}(0.73 \mathrm{M}), \mathrm{Cu}=14.9 \mathrm{~g} \mathrm{~L}^{-1}(0.23 \mathrm{M})$, and $\mathrm{pH}=11.5$. Si was applied considering the amount of 0.0 (control), 1.0, 2.0, 3.0, and $4.0 \mathrm{~g} \mathrm{~L}^{-1}$, divided into three applications at 15, 29, and 43 days after transplantation (DAT), respectively, which are the initial, intermediate, and final flowering periods. The spraying amount was divided into parts to avoid a phytotoxic effect on the tomatoes. The $\mathrm{Si}$ amount was balanced with $\mathrm{K}$ and $\mathrm{Cu}$ using $\mathrm{K}_{2} \mathrm{O}$ and $\mathrm{Cu}_{2} \mathrm{O}$, considering only the Si content a factor of variation. Thus, all doses contained concentrations of $\mathrm{K}_{2} \mathrm{O}$ and $\mathrm{Cu}$, being $0.011 \mathrm{M}$ and $0.0088 \mathrm{M}$, respectively. A solution of $50 \mathrm{~mL}$ was applied per plant, where this was applied uniform and covering the entire area of the plant. At the time of application, the soil was covered with a plastic tarpaulin to avoid contamination.

The soil water potential was monitored using $\mathrm{ECH}_{2} \mathrm{O}$ EC-5 soil moisture sensors $\left(\mathrm{ECH}_{2} \mathrm{O}\right.$ EC-5, Decagon Devices, Pulman, WA, USA), recording the data using data loggers (Em50, Decagon Devices, Pullman, WA, USA). The sensors were calibrated following Antunes Júnior (2018) [17].

The water was applied using drip irrigation, starting the irrigation when the soil water potential reached -30 and $-60 \mathrm{kPa}$, and ending when the potential reached $-10 \mathrm{kPa}$. 
The plant stem diameter and height, leaf area [18], relative chlorophyll index (CRI)—using a chlorophyll meter (ChlorofiLOG CFL 1030, Falker Automação Agrícola, Porto Alegre, RS, Brazil) [19]—and yield at 20, 34, and 48 DAT (five days after Si application) were measured.

The leaf gas exchange rate $\left(A_{n}, g s, E\right.$, and $\left.C i\right)$ were measured using an infrared gas analyzer (IRGA, ADC Bioscientific Ltd., Hoddesdon, Herts, England) coupled with a fluorometer of a $6.25 \mathrm{~cm}^{2}$ leaf chamber (iFL, ADC Bioscientific Ltd., Hoddesdon, Herts, England). A photosynthetic activity radiation lamp provided supplementary light at a photon flux density of $1000 \mu \mathrm{mol} \mathrm{m}^{2} \mathrm{~s}^{-1}$, and the airflow was set at $150 \mu \mathrm{mol} \mathrm{mol}^{-1}$. The measurements were done on three leaves (from an intermediate position on the stem) for each plant, during the period from 9:00 a.m. to 10:00 a.m., when the highest stability of the gases in the atmosphere occurs [20].

The data obtained were subjected to analysis of variance by the $F$ test. For the soil water status factor, the $F$ test $(p<0.05)$ was conclusive, as there were only two stresses, while the polynomial regression analysis was used for the Si doses, with its significance verified by the LSD test $(p<0.05)$.

\section{Results}

There was a significant effect of soil water potentials on plant height and stem diameter at 48 DAT (Table 1). It is possible to observe a significant effect for plant height on the interaction between the five doses of Si and the two water potentials of the soil at 48 DAT (Table 1). This interaction between Si and water potential was not observed at 20 and 34 DAT. According to the $F$ test ( $p$-value $>0.05)$, the leaf area, the number of fruits, the relative chlorophyll index, and the yield were statistically equal (Table S1), regardless of the evaluation time, silicon doses, and water tension applied to the soil (Table 1).

Table 1. ANOVA summary of the biometric variables, namely, the stem height $(\mathrm{cm})$, diameter $(\mathrm{mm})$, leaf area $\left(\mathrm{cm}^{2}\right)$, fruits, relative chlorophyll index $(\mathrm{RCI})$, and yield $\left(\mathrm{t} \mathrm{ha}^{-1}\right)$ with application of five doses of $\mathrm{Si}$ (0.0 (control), 1.0, 2.0, 3.0 and $4.0 \mathrm{~g} \mathrm{~L}^{-1}$ ) and two soil water potentials (-30 and $-60 \mathrm{kPa}$ ), at 20, 34, and 48 days after transplantation (DAT).

\begin{tabular}{|c|c|c|c|c|c|c|c|c|c|c|c|c|c|c|}
\hline & \multirow{3}{*}{$\begin{array}{l}\text { V. F. } \\
\text { Block }\end{array}$} & \multirow{3}{*}{$\begin{array}{c}\text { DF } \\
3\end{array}$} & \multicolumn{12}{|c|}{ Mean Square } \\
\hline & & & \multicolumn{2}{|c|}{ Height } & \multicolumn{2}{|c|}{ Diameter } & \multicolumn{2}{|c|}{ Leaf Area } & \multicolumn{2}{|c|}{ Fruits } & \multicolumn{2}{|c|}{ RCI } & \multicolumn{2}{|c|}{ Yield } \\
\hline \multirow{6}{*}{$\begin{array}{l}\text { 离 } \\
\text { ○ิ }\end{array}$} & & & 33.83 & ns & 7.51 & ns & 2.14 & ns & - & & 25.52 & ns & - & \\
\hline & Dose (D) & 4 & 14.54 & ns & 0.55 & $\mathrm{~ns}$ & 0.58 & ns & - & & 9.09 & ns & - & \\
\hline & Tension $(\mathrm{T})$ & 1 & 15.63 & ns & 1.60 & ns & 3.89 & ns & - & & 14.76 & ns & - & \\
\hline & $\mathrm{D} \times \mathrm{T}$ & 4 & 60.84 & ns & 2.58 & ns & 7.74 & ns & - & & 31.65 & ns & - & \\
\hline & Residual & 27 & 30.49 & - & 1.66 & - & 1.70 & - & - & & 13.24 & - & - & \\
\hline & C.V. $(\%)$ & - & 16.52 & - & 23.94 & - & 53.86 & - & - & & 9.73 & - & - & \\
\hline \multirow{6}{*}{ 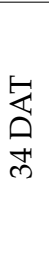 } & Block & 3 & 80.63 & ns & 3.70 & ns & 13.59 & ns & - & & 7.13 & ns & - & \\
\hline & Dose (D) & 4 & 47.94 & ns & 2.14 & ns & 1.61 & ns & - & & 6.81 & ns & - & \\
\hline & Tension $(\mathrm{T})$ & 1 & 319.23 & ns & 0.02 & ns & 9.49 & ns & - & & 7.57 & ns & - & \\
\hline & $\mathrm{D} \times \mathrm{T}$ & 4 & 266.16 & ns & 5.41 & ns & 2.50 & ns & - & & 5.93 & ns & - & \\
\hline & Residual & 27 & 101.03 & - & 2.73 & - & 2.43 & - & - & & 13.28 & - & - & \\
\hline & C.V. $(\%)$ & - & 18.15 & - & 20.00 & - & 30.37 & - & - & & 10.13 & - & - & \\
\hline \multirow{6}{*}{$\begin{array}{l}\text { 乨 } \\
\text { O } \\
\text { 市 }\end{array}$} & Block & 3 & 477.43 & * & 8.59 & ns & 1.00 & ns & 14.69 & ns & 6.92 & ns & 16.06 & ns \\
\hline & Dose (D) & 4 & 77.91 & ns & 2.81 & ns & 1.09 & ns & 7.66 & ns & 36.80 & ns & 101.75 & ns \\
\hline & Tension $(\mathrm{T})$ & 1 & 1166.40 & $*$ & 26.08 & $* *$ & 1.65 & ns & 11.02 & ns & 0.46 & ns & 11.034 & ns \\
\hline & $\mathrm{D} \times \mathrm{T}$ & 4 & 430.34 & $*$ & 3.49 & ns & 2.29 & ns & 23.46 & ns & 6.27 & ns & 18.248 & ns \\
\hline & Residual & 27 & 134.9 & - & 2.99 & - & 2.31 & - & 20.82 & - & 36.91 & - & 78.01 & - \\
\hline & C.V. (\%) & - & 13.75 & - & 17.63 & - & 34.37 & - & 73.90 & - & 13.76 & - & 56.97 & - \\
\hline
\end{tabular}

(-) no values; $\left({ }^{*}\right)$ significant at $5 \%$ by the $F$ test; $\left({ }^{* *}\right)$ significant at $1 \%$ by the $F$ test; and $\left({ }^{\text {ns }}\right)$ not significant at $5 \%$ by the $F$ test. 
At a soil water potential of $-60 \mathrm{kPa}$, the stem diameter and plant height had lower values than those with a water potential in the soil of $-30 \mathrm{kPa}$. The percentage reduction was $12.1 \%$ and $15.2 \%$, respectively, for the height and diameter (Figure 1).
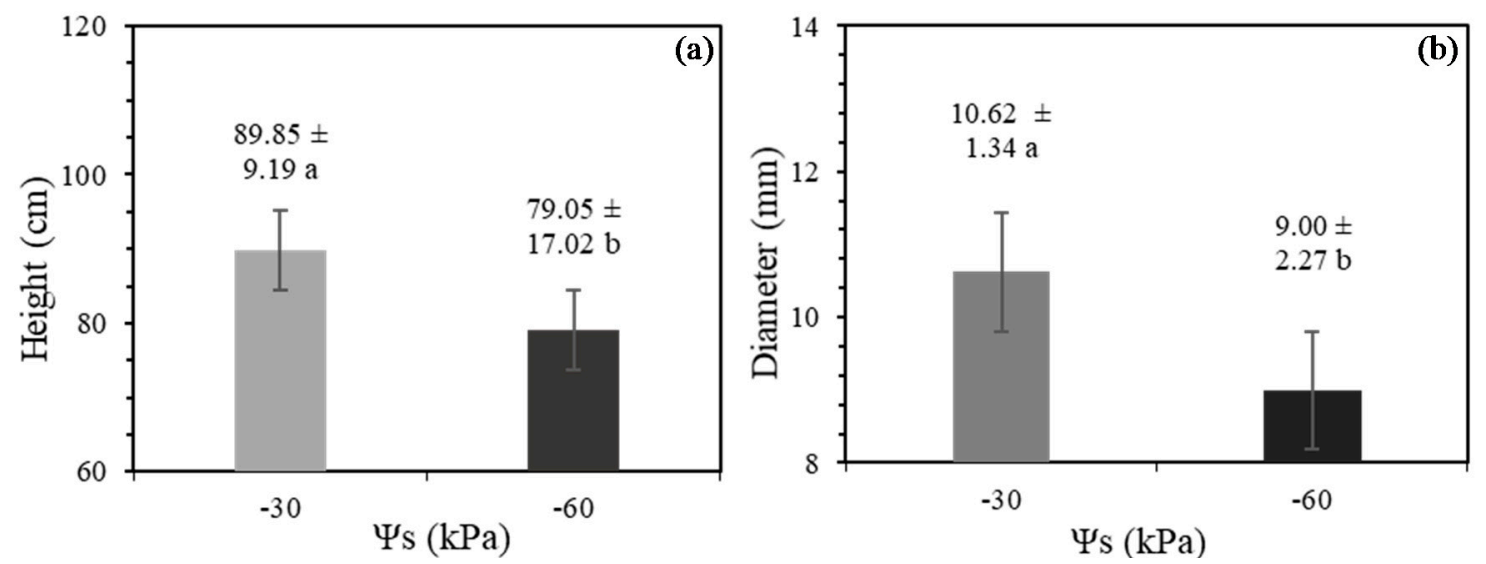

Figure 1. Plant height (a) and stem diameter (b) of tomatoes under potential water in the soil ( $\Psi$ s) of -30 and $-60 \mathrm{KPa}$ at $48 \mathrm{DAT}$. Different letters represent statistically relevant differences at $5 \%$ by the $F$ test.

Figure 2 shows a regression analysis between the interaction of $\mathrm{Si}$ doses and potential water in the soil at the height variable at $48 \mathrm{DAT}(p$-value $<0.05)$. A regression analysis between the $\mathrm{Si}$ doses and stem height (Figure 2) showed that there was a significant effect of $\mathrm{Si}$ doses submitted to $\Psi \mathrm{s}=-30 \mathrm{kPa}$ ( $p$-value $<0.05$ ); there was an increase in the height of the main stem, reaching $96.29 \mathrm{~cm}$, with an estimated dose of $2.60 \mathrm{~g} \mathrm{~L}^{-1}$ of silicon, with a subsequent reduction with the application of higher doses. The same effect was not observed at $\Psi$ s $=-60 \mathrm{kPa}(p$-value $>0.05)$.

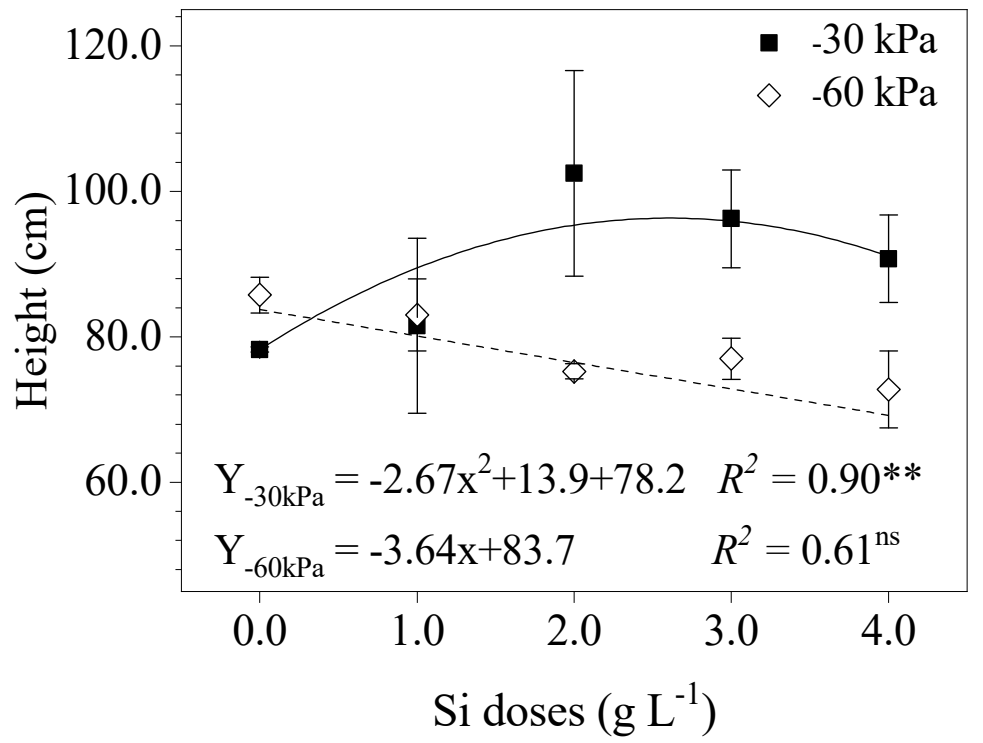

Figure 2. Plant height of the tomatoes under different water potentials in the soil in interaction with $\mathrm{Si}$ application at 48 DAT. $\left.{ }^{* *}\right)$ significant at $1 \%$ by $F$ test; and $\left({ }^{\text {ns }}\right)$ not significant at $5 \%$ by $F$ test.

Table 2 shows the results of the analysis of variance (ANOVA) of the gas exchange parameters of tomato plants subjected to two soil water potentials and five doses of $\mathrm{Si}$, at 20, 34, and 48 DAT. There was a significant effect in the $F$ test regarding the interaction between the five doses of $\mathrm{Si}$ and the two water potentials of the soil for all parameters of gas exchange of tomatoes at 20, 34, and 48 DAT. 
Table 2. ANOVA summary of the tomato gas exchange, namely, the transpiration rate $(E)$, stomatal conductance $(g s)$, internal $\mathrm{CO}_{2}$ concentration $(\mathrm{C} i)$, and net photosynthesis assimilation rate $\left(A_{n}\right)$ subjected to five doses of $\mathrm{Si}\left(0.0\right.$ (control), 1.0, 2.0, 3.0 and $\left.4.0 \mathrm{~g} \mathrm{~L}^{-1}\right)$ and two soil water potentials ( -30 and $-60 \mathrm{kPa})$, at 20,34 , and 48 DAT.

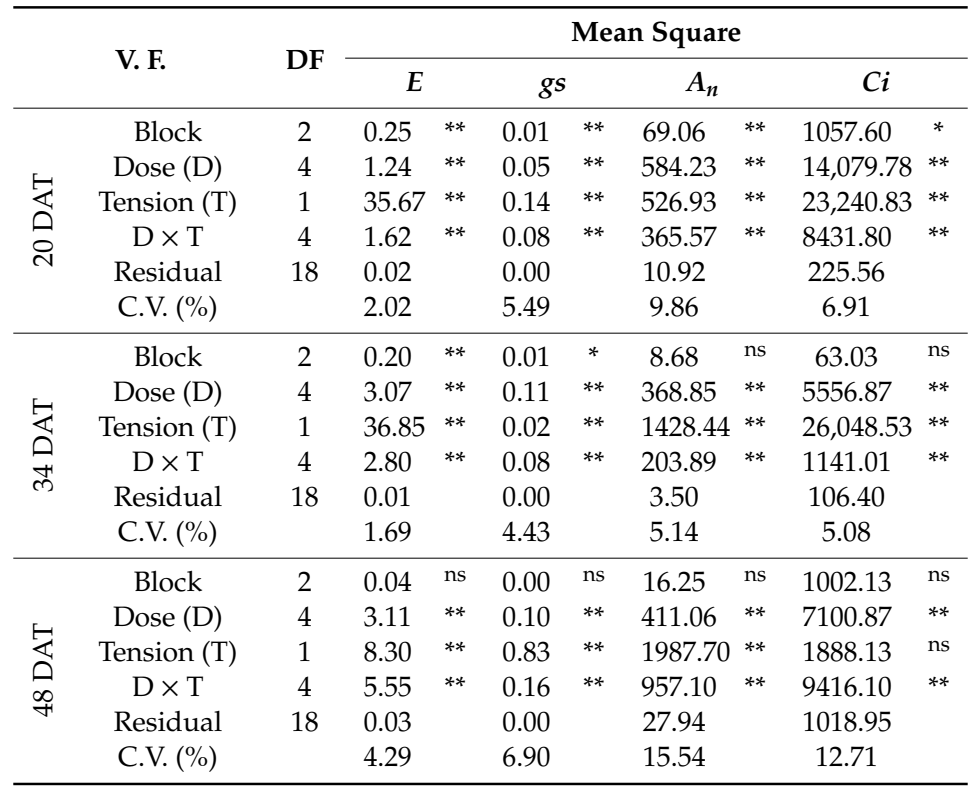

${ }^{*}$ ) significant at $5 \%$ by the $F$ test; $\left({ }^{* *}\right)$ significant at $1 \%$ by the $F$ test; and $\left({ }^{\text {ns }}\right)$ not significant at $5 \%$ by the $F$ test.

The responses of the transpiration rate $(E)$, stomatal conductance $(g s)$, net photosynthesis assimilation rate $\left(A_{n}\right)$, and internal $\mathrm{CO}_{2}$ concentration $(\mathrm{C} i)$ are shown, respectively, in Figures 3-5, as a function of the Si amount $\left(\mathrm{g} \mathrm{L}^{-1}\right)$ subjected to the two levels of water potentials $(-30$ and $-60 \mathrm{kPa})$, at 20,34 , and 48 DAT.
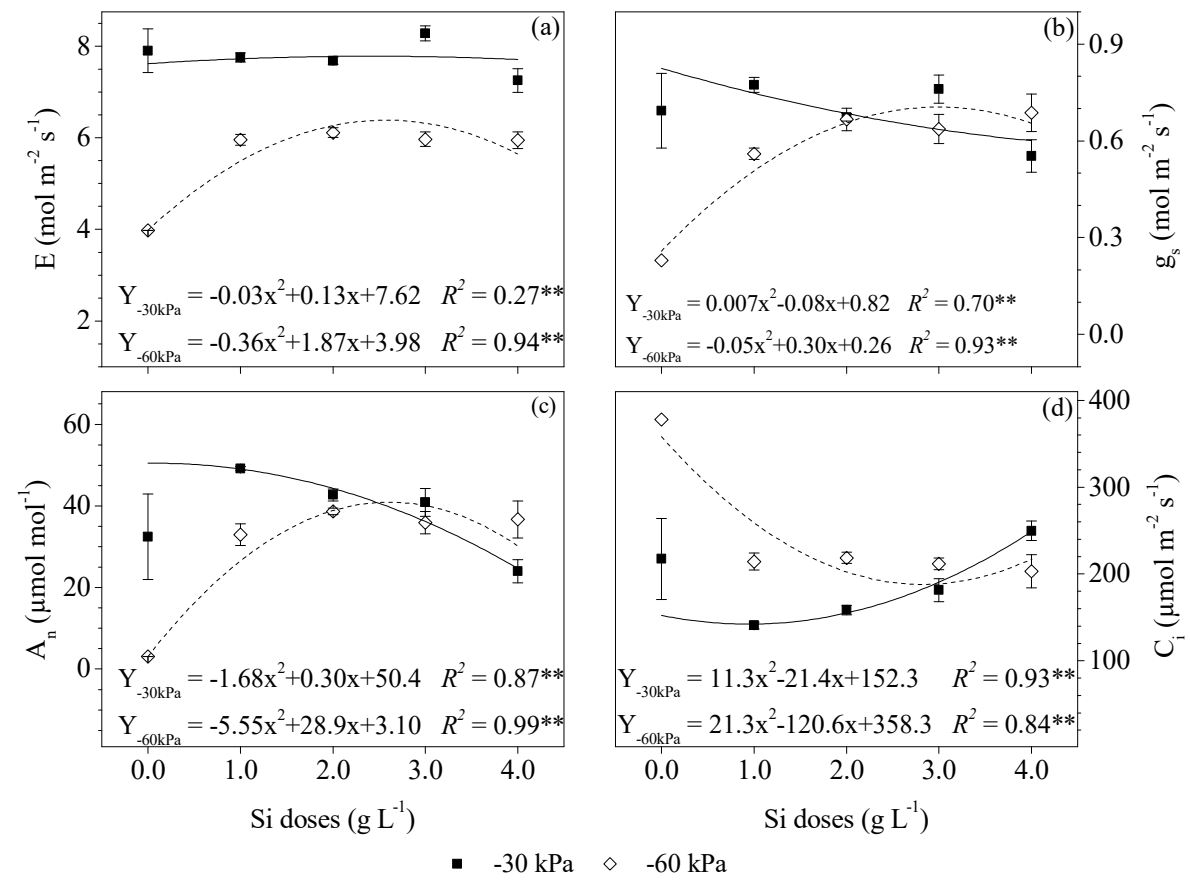

Figure 3. Responses of transpiration rate (a), stomatal conductance (b), net photosynthesis assimilation rate $(\mathbf{c})$, and internal concentration of $\mathrm{CO}_{2}(\mathbf{d})$ to different amount of $\mathrm{Si}\left(\mathrm{g} \mathrm{L}^{-1}\right)$ subjected to two levels of water restriction $(-30$ and $-60 \mathrm{kPa})$ at $20 \mathrm{DAT}$. $\left.{ }^{* *}\right)$ significant at $1 \%$ by $F$ test. 

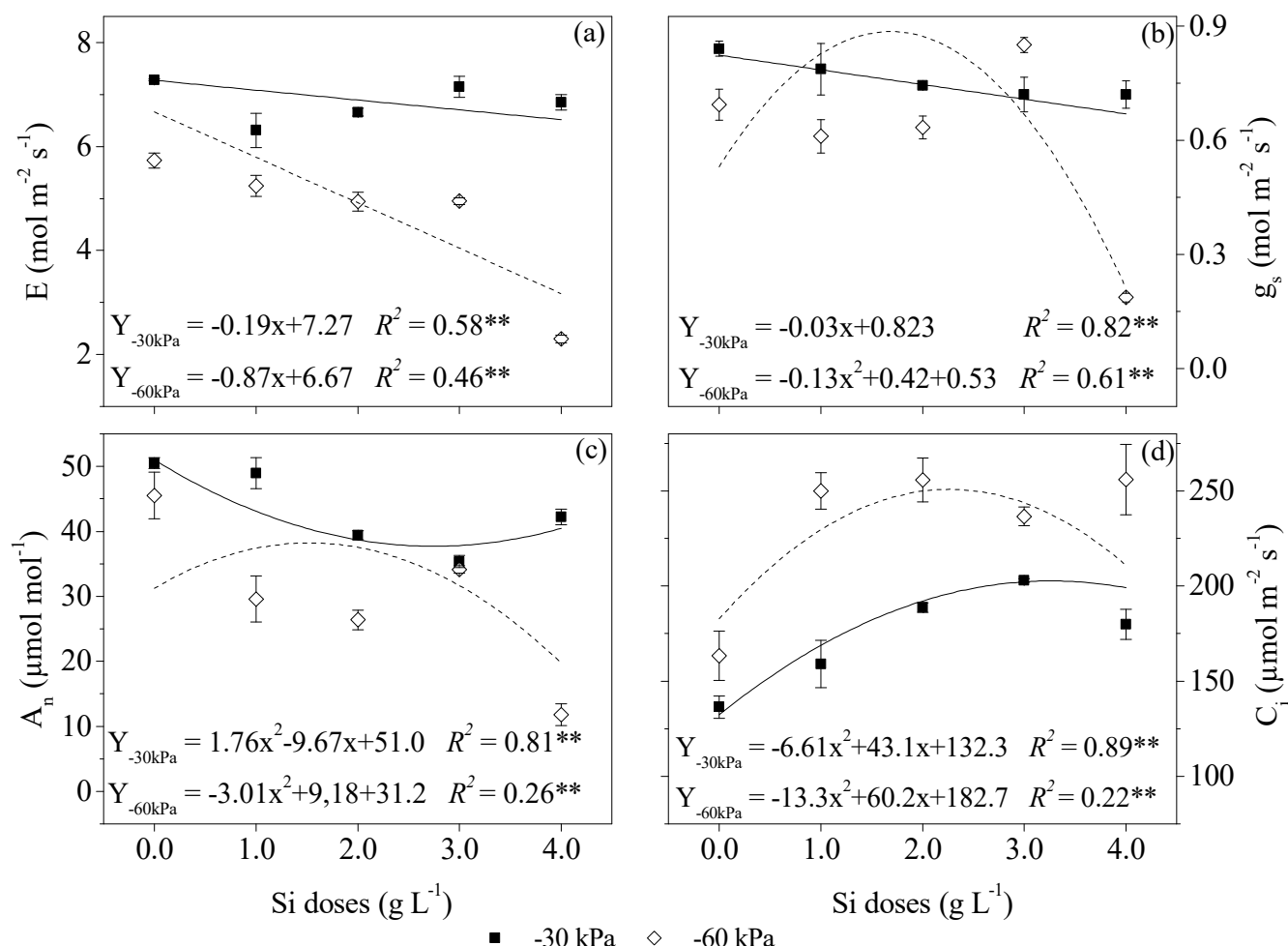

Figure 4. Responses of the transpiration rate (a), stomatal conductance (b), net photosynthesis assimilation rate $(\mathbf{c})$, and internal concentration of $\mathrm{CO}_{2}(\mathbf{d})$ to the different doses of $\mathrm{Si}\left(\mathrm{g} \mathrm{L}^{-1}\right)$ subjected to two levels of water restriction $(-30$ and $-60 \mathrm{kPa})$ at 34 DAT. $\left.{ }^{* *}\right)$ significant at $1 \%$ by $F$ test.
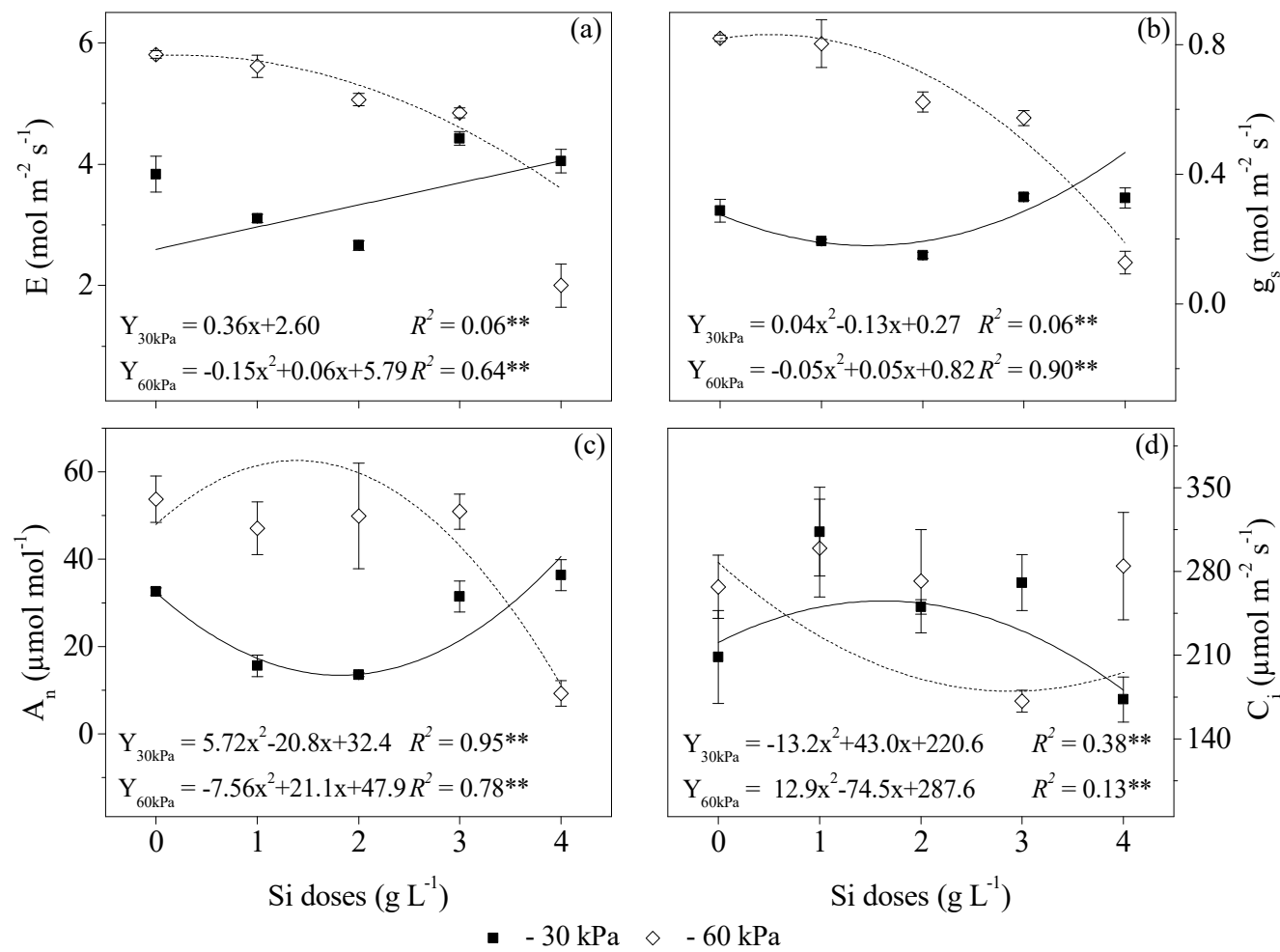

Figure 5. Responses of the transpiration rate (a), stomatal conductance (b), net photosynthesis assimilation rate (c), and the internal concentration of $\mathrm{CO}_{2}(\mathbf{d})$ for different doses of $\mathrm{Si}\left(\mathrm{g} \mathrm{L}^{-1}\right)$ subjected to two levels of water restriction $(-30$ and $-60 \mathrm{kPa})$ at $48 \mathrm{DAT}$. $\left.{ }^{* *}\right)$ significant at $1 \%$ by $F$ test. 
The gas exchange evaluation showed significant differences in the responses to $\mathrm{Si}$ doses subjected to soil water potentials of -30 and $-60 \mathrm{kPa}(p$-value $<0.05)$ (Figure 3). At a soil water potential of $-60 \mathrm{kPa}$, the $\mathrm{Si}$ amount of $2.60 \mathrm{~g} \mathrm{~L}^{-1}$ promoted in the maximum transpiration (E), reaching $6.41 \mathrm{~mol} \mathrm{~m}^{-1} \mathrm{~s}^{-1}$, $49.6 \%$ higher than the control treatment.

Stomatal conductance $(g s)$ showed a different behavior in relation to the application of silicon doses at different soil water potentials (Figure 3). There was a decline in $g s$ with the tension of $-30 \mathrm{kPa}$, up to the dose of $4 \mathrm{~g} \mathrm{~L}^{-1}$ of $\mathrm{Si}$, reaching $0.59 \mathrm{~mol} \mathrm{~m}^{-2} \mathrm{~s}^{-1}$. While, at the tension of $-60 \mathrm{kPa}$, an increase in gas occurred until reaching $0.71 \mathrm{~mol} \mathrm{~m}^{-2} \mathrm{~s}^{-1}$, with an application of $3.00 \mathrm{~g} \mathrm{~L}^{-1}$ of Si (Figure 3). The photosynthetic rate $\left(A_{n}\right)$ decreased with the increase in silicon doses with the tension of $-30 \mathrm{kPa}$, in which the estimated application of $0.09 \mathrm{~g} \mathrm{~L}^{-1}$ of Si presented a higher photosynthetic rate, $50.41 \mu \mathrm{mol} \mathrm{mol}^{-1}$. In the soil with a tension of $-60 \mathrm{kPa}, A_{n}$ increased until the estimated dose of $2.60 \mathrm{~g} \mathrm{~L}^{-1}$, reaching $40.72 \mu \mathrm{mol} \mathrm{mol}{ }^{-1}$. The internal concentration of $\mathrm{CO}_{2}(\mathrm{C} i)$ showed a similar behavior than photosynthesis, showing a second-order polynomial adjustment, reaching a $\mathrm{Ci}$ of 142.168 and $187.59 \mu \mathrm{mol} \mathrm{m}{ }^{-2} \mathrm{~s}^{-2}$, with an application of 0.94 and $2.83 \mathrm{~g} \mathrm{~L}^{-1}$ of Si, respectively, at the soil water potentials of -30 and $-60 \mathrm{kPa}$ (Figure 3).

There was a decrease in gas exchange at $34 \mathrm{DAT}$, which was affected by the soil water potential (Figure 4). The photosynthetic rate and internal $\mathrm{CO}_{2}$ concentration had a statistically significant result for $\mathrm{Si}$ amount at a soil water potential of $-30 \mathrm{kPa}$; however, the statistical adjustment was poor, with a low determination coefficient $\left(R^{2}<0.26\right)$ (Figure 4$)$.

$E$ and $g s$ were reduced with the increase in $\mathrm{Si}$ at a soil water potential of $-30 \mathrm{kPa}$, at $34 \mathrm{DAT}$, where reductions, respectively, of $5.9 \%$ and $14.3 \%$ were observed between the control and maximum $\mathrm{Si}$ amount. The $g s$ obtained a reduction of $73.1 \%$ when comparing the control to the maximum Si amount at a soil water potential of $-60 \mathrm{kPa}$ (Figure 4). Tomato showed higher rates of $g s\left(0.86 \mathrm{~mol} \mathrm{~m}^{-2} \mathrm{~s}^{-1}\right)$, $A_{n}\left(38.20 \mu \mathrm{mol} \mathrm{mol}^{-1}\right)$, and $C i\left(250.82 \mu \mathrm{mol} \mathrm{m}^{-2} \mathrm{~s}^{-2}\right)$ with foliar applications of $1.61,1.52$, and $2.26 \mathrm{~g} \mathrm{~L}^{-1}$ of $\mathrm{Si}$, respectively (Figure 4). The internal $\mathrm{CO}_{2}$ concentration subjected to a lower water restriction ( $\Psi \mathrm{s}=-30$ ) also increased to $202.55 \mu \mathrm{mol} \mathrm{m}{ }^{-2} \mathrm{~s}^{-2}$ with the application of the estimated dose of $3.26 \mathrm{~g} \mathrm{~L}^{-1}$ of Si (Figure 4).

At $48 \mathrm{DAT}$, the treatments with a soil water potential of $-60 \mathrm{kPa}$ showed better gas exchange rates at $\mathrm{Si}$ doses between 1 and $3 \mathrm{~g} \mathrm{~L}^{-1}$ when compared to $-30 \mathrm{kPa}$. An amount of 0.2 and $0.5 \mathrm{~g} \mathrm{~L}^{-1}$ of Si promoted the highest values of $E\left(5.79 \mathrm{~mol} \mathrm{~m}^{-2} \mathrm{~s}^{-1}\right)$ and $\mathrm{gs}\left(0.83 \mathrm{~mol} \mathrm{~m}^{-2} \mathrm{~s}^{-1}\right)$, respectively, at a soil water potential of $-60 \mathrm{KPa}$; however, with increasing this amount until $4 \mathrm{~g} \mathrm{~L}^{-1} \mathrm{of} \mathrm{Si}$, a reduction in $E$ and $g s$ of about $24 \%$ and $35 \%$, respectively, was seen. This treatment differs from that observed for $A n$, in which the net assimilation rate of photosynthesis did not differ significantly between the control treatment and a dose of $3 \mathrm{~g} \mathrm{~L}^{-1}$. However, a dose of $4 \mathrm{~g} \mathrm{~L}^{-1}$ showed a mean reduction of $81.7 \%$ on $A n$ at a soil water potential of $-60 \mathrm{KPa}$ (Figure 5).

\section{Discussion}

The transpiration rate $(E)$, stomatal conductance $(g s)$, and net photosynthesis assimilation rate $\left(A_{n}\right)$ were lower when plants were subjected to a water deficit ( $\left.\Psi \mathrm{s}=-60 \mathrm{kPa}\right)$ at 20 and $34 \mathrm{DAT}$ (Figures 2 and 3). The foliar application of Si influenced the gas exchange regardless of the condition of the water deficit induced during the cultivation of plants, leading to a greater effect at a soil water potential of $-60 \mathrm{kPa}$. Improvements in plant development by applying $\mathrm{Si}$ under water deficit conditions have been documented for many crops, including sorghum [21], rice [22], and tomatoes [23]. This improvement occurs because Si provides protection against the oxidative stress induced by drought, changes the behavior of the antioxidant enzyme system of the chloroplast, protects against lipid peroxidation of the membrane caused by environmental stresses, and reduces the accumulation of $\mathrm{H}_{2} \mathrm{O}_{2}$ and $\mathrm{O}_{2}$ [23,24]. According to Rizwan et al. (2015) [25], $\mathrm{Si}$ is deposited in the leaf epidermis, acting as a physical barrier and preventing water loss by plants, mainly due to its role in the antioxidant, photosynthetic, and osmotic system of plants. 
$C i$ had an inversely proportional relation to $E, g S$, and $A_{n}$ across the different $S i$ amounts and soil water potentials. When plants were subjected to a water deficit $\left(\Psi_{\mathrm{s}}=-60 \mathrm{kPa}\right)$, and there was a harmful effect, $\mathrm{C} i$ showed a higher concentration (Figures 2-4). The first response of plants to a water deficit is to close stomata to prevent water loss through transpiration [26]. This response can result in a decreased leaf water potential and leaf turgor. Gao et al. found that Si could act as a moderator of cuticular and stomatic transpiration [27]. Si is deposited below the cuticle layer on leaves, decreasing the rate of transpiration and maintaining a high relative water content in leaves, leading plants to not consume more water when it has a high osmotic potential [28], justifying the higher $\mathrm{C} i$ indexes found in this study.

Studies have been carried out to find the mechanism of tolerance to abiotic stresses in plants under the influence of $\mathrm{Si}[14,29,30]$. The use of $\mathrm{Si}$ increase plant tolerance to water deficits due to $\mathrm{Si}$ delaying the degradation of chlorophyll protein complexes [22], enabling the process of absorption, transfer, distribution, and transformation of light energy [31]. Si not only increases the content of photosynthetic pigments but also increases the basal quantum yield and the maximum photochemical efficiency of photosystem II [32]. Since there was an increase in the quantum efficiency of photosystem II, there is a decrease in the loss of cellular electrolytes and free proline content, which allows for higher biomass production and plant growth [33].

The beneficial effects of Si on plants subjected to drought can be partially attributed to its positive impact on the state of the water and on the photosynthesis of plants [34]. It is verified that Si also influences the concentration of inorganic phosphorus in leaves [35]. Inorganic phosphorus is an important component and affects the synthesis of ATP in the chloroplast; in its absence, there is a reduction in photosynthetic rates, transpiration, and stomatal conductance [36]. According to Liang et al. (2006), Si maintains membrane fluidity by adjusting the phospholipid and protein levels, increasing the glutathione concentration [37], which helps to reduce the oxidative damage to enzymes induced by active oxygen species and improves the membrane's H+-ATPase plasmatic activity, thus causing an improvement in photosynthesis by adding Si under water deficit conditions [38].

Transpiration was regulated at $20 \mathrm{DAT}$ when $\mathrm{Si}$ was applied (Figure 2). E increased with doses of Si between 1 and $4 \mathrm{~g} \mathrm{~L}^{-1}$ for $\Psi \mathrm{s}=-60 \mathrm{kPa}$ in relation with the control at $20 \mathrm{DAT}$. However, at 34 and 48 DAT (Figures 3 and 4), there is a decrease in $E$ when applied with Si. Liang et al. explained that the accumulation of polymerized silicic acid on epidermal cell walls could form bonds between hydrogen, water, and hydrated silica, making water molecules less likely to escape from the leaf surface [39].

$\mathrm{Si}$ increases the $g s$ and $E$ of plants due to an improved water status in plants under water deficit due to an increased water uptake by the roots [38]. Sonobe et al. suggested that the addition of Si to plants increases the water uptake by roots under water-stress conditions through the accumulation of soluble sugars and amino acids [40]. Proline is an amino acid that protects plants against drought and stress due to salinity, maintaining osmotic adjustment, metabolizing antioxidants, being modulators of reactive oxygen species and the main enzyme components of the antioxidant defense system, as well as ensuring the integrity of cell membranes [41]. However, Pei et al. found that the concentration of proline increases in wheat leaves under water stress, producing symptoms along with the plant and not acting as a cause of tolerance to water stress and that the addition of silicon decreases the accumulation of proline [42]. Cao et al. found that $\mathrm{Si}$ restricts the accumulation of reactive oxygen species induced by drought, promoting energy dissipation in tomato leaves and significantly improving the gas exchange parameters such as $g s, E$, and $A_{n}$ [43].

The water deficit and Si doses did not cause significant effects on the relative chlorophyll index (Table 1). A lower level of chlorophyll or unchanged levels during water stress has been reported for other species, depending on the duration and severity of the water deficit [44]. The relative chlorophyll index $(\mathrm{RCI})$ is an important factor in plant productivity metrics since it is directly proportional to the photosynthesis rate for biomass production [45]. These results corroborate the lack of significance of the results related to the highest biometric parameter. 
The water status of a plant is a key parameter that acts as an important regulator of the physiological and molecular responses during low water availability [46]. To minimize the damage caused by water deficits, plants have developed several strategies to adapt to water stress. Si is listed as a beneficial element that improves drought tolerance in plants [34]. Studies have shown a positive effect of Si on the tolerance to water stress in tomatoes. Si significantly increases the biomass of tomatoes grown under water-stress conditions. They have also indicated that $\mathrm{Si}$ improves the drought tolerance of non-Si-accumulating plants, suggesting that $\mathrm{Si}$-based fertilizers could be used in tomato production in arid areas $[47,48]$.

\section{Conclusions}

Supplementation of silicon $(\mathrm{Si})$ improves the gas exchange rates of tomatoes at a soil water potential of $-60 \mathrm{KPa}$. The supplementation of plants with $\mathrm{Si}$ increases the stomatal conductance, transpiration, and photosynthesis rate. These effects result in the calculation of an optimal $\mathrm{CO}_{2}$ concentration, which avoids photoinhibition and maintains the non-difference between the biometric variables of the treatments. Doses greater than $3.0 \mathrm{~g} \mathrm{~L}^{-1}$ under the potential soil water of $-60 \mathrm{kPa}$ are harmful to tomato crops for industrial processing at 34 and 48 days after transplantation. A foliar application up to $2.8 \mathrm{~g} \mathrm{~L}^{-1}$ promotes an increase in the net assimilation rate of photosynthesis $\left(A_{n}\right)$, stomatal conductance $(g s)$, and transpiration rate $(E)$. Thus, Si shows potential to be used in strategies regarding limited water availability to tomato, to improve its gas exchange.

Supplementary Materials: The following are available online at http://www.mdpi.com/2073-4395/10/11/1715/s1, Table S1: ANOVA summary of the biometric variables, namely, the stem height $(\mathrm{cm})$, diameter $(\mathrm{mm})$, leaf area $\left(\mathrm{cm}^{2}\right)$, fruits, relative chlorophyll index (RCI), and yield $\left(\mathrm{t} \mathrm{ha}^{-1}\right)$ of plants subjected to -30 and $-60 \mathrm{kPa}$ at 20, 34, and 48 days after transplantation (DAT).

Author Contributions: D.H.M.d.M.; M.M.; A.M.B.; R.A.F.; F.S.R.d.L.; R.B.; H.F.E.d.O.; R.d.M.P. and R.B. have contributed equally to the research design, development, and the writing of the manuscript. All authors have read and agreed to the published version of the manuscript.

Funding: This research was funded by Coordination for the Improvement for Higher Level Personnel-CAPES, was funded by Postgraduate Program in Agronomy-Federal University of Goiás, (UFG), Cerrado Irrigation Postgraduate Program-Goiano Federal Institute, and National Council for Scientific and Technological Development (CNPq), process number 306329-2019-0.

Acknowledgments: The authors thank the Postgraduate Program in Agronomy-Federal University of Goiás, (UFG); the Coordination for the Improvement for Higher Level Personnel (CAPES), National Council for Scientific and Technological Development (CNPq) for the financial and structural support to conduct this study and, Goiano Federal Institute for the financial assistance for the publication of the paper.

Conflicts of Interest: The authors declare no conflict of interest

\section{References}

1. Madhu, M.; Hatfield, J.L. Interaction of Carbon Dioxide Enrichment and Soil Moisture on Photosynthesis, Transpiration, and Water Use Efficiency of Soybean. Agric. Sci. 2014, 5, 410-429. [CrossRef]

2. Tomás, M.; Medrano, H.; Escalona, J.M.; Martorell, S.; Pou, A.; Ribas-Carbó, M.; Flexas, J. Variability of water use efficiency in grapevines. Environ. Exp. Bot. 2014, 103, 148-157. [CrossRef]

3. Da Silva, F.G.; Dutra, W.F.; Dutra, A.F.; de Oliveira, I.M.; Filgueiras, L.M.B.; Melo, A.S.; da Dutra, W.F.; Dutra, A.F.; Oliveira, I.M. Trocas gasosas e fluorescência da clorofila em plantas de berinjela sob lâminas de irrigação. Rev. Bras. Eng. Agrícola Ambient. 2015, 19, 946-952. [CrossRef]

4. Patanè, C.; Scordia, D.; Testa, G.; Cosentino, S.L. Physiological screening for drought tolerance in Mediterranean long-storage tomato. Plant Sci. 2016, 249, 25-34. [CrossRef]

5. Mesquita, M.; Paula, A.D.S.D.; Pureza, A.M.; Oliveira HFE de Casaroli, D. Qualitive Characteristics of Processing Tomato Cultivated Under Water Deficit Induced in the Vegetative Growth Stage. Chem. Eng. Trans. 2019, 75, 175-180. [CrossRef]

6. Da Silva, C.J.; da Silva, C.A.; de Freitas, C.A.; Golynski, A.; da Silva, L.F.M.; Frizzone, J.A. Tomato water stress index as a function of irrigation depths. Rev. Bras. Eng. Agríc. Ambient. 2018, 22, 95-100. [CrossRef] 
7. Cui, J.; Shao, G.; Lu, J.; Keabetswe, L.; Hoogenboom, G.; Cui, J.; Shao, G.; Lu, J.; Keabetswe, L.; Hoogenboom, G. Yield, quality and drought sensitivity of tomato to water deficit during different growth stages. Sci. Agric. 2020, 77. [CrossRef]

8. Adrees, M.; Ali, S.; Rizwan, M.; Zia-ur-Rehman, M.; Ibrahim, M.; Abbas, F.; Farid, M.; Qayyum, M.F.; Irshad, M.K. Mechanisms of silicon-mediated alleviation of heavy metal toxicity in plants: A review. Ecotoxicol. Environ. Saf. 2015, 119, 186-197. [CrossRef]

9. Flores, R.A.; Arruda, E.M.; de Souza, J.P., Jr.; de Prado, M.R.; dos Santos, A.C.A.; Aragão, A.S.; Pedreira, N.G.; da Costa, C.F. Nutrition and production of Helianthus annuus in a function of application of leaf silicon. J. Plant Nutr. 2019, 42, 137-144. [CrossRef]

10. Barbosa Filho, M.P.; Snyder, G.H.; Fageria, N.K.; Datnoff, L.E.; Silva, O.F. Silicato de cálcio como fonte de silício para o arroz de sequeiro. Rev. Bras. Ciência Solo 2001, 25, 325-330. [CrossRef]

11. Ma, J.F.; Yamaji, N. Silicon uptake and accumulation in higher plants. Trends Plant Sci. 2006, 11, $392-397$. [CrossRef]

12. Mauad, M.; Crusciol, C.A.C.; Nascente, A.S.; Grassi Filho, H.; Lima, G.P.P. Características bioquímicas nas folhas de cultivares de arroz de terras altas em função de silício e estresse hídrico. Rev. Ciência Agronômica 2016, 47, 532-539. [CrossRef]

13. Flores, R.A.; Souza Junior, J.P.; Santos, Á.S.; Cruz, F.J.R.; Campos, C.N.S.; Júnior, G.B.S.; de Prado, R.M. Importância do silício na bioquímica e fisiologia das plantas. In Nutrição e Adubação de Grandes Culturas $\mathrm{Na}$ Região Do Cerrado; Flores, R.A., Cunha, P.P., Marchão, R.L., Moraes, M.F., Eds.; Gráfica UFG: Goiânia, Brazil, 2019; pp. 79-98.

14. Meharg, C.; Meharg, A.A. Silicon, the silver bullet for mitigating biotic and abiotic stress, and improving grain quality, in rice? Environ. Exp. Bot. 2015, 120, 8-17. [CrossRef]

15. de Jesus, E.G.; de Fatima, R.T.; Guerrero, A.C.; de Araújo, J.L.; Brito, M.E.B.; de Jesus, E.G.; de Fatima, R.T.; Guerrero, A.C.; Brito, M.E.B. Growth and gas exchanges of arugula plants under silicon fertilization and water restriction. Rev. Bras. Eng. Agrícola Ambient. 2018, 22, 119-124. [CrossRef]

16. Alvares, C.A.; Sapé, J.L.; Sentelhas, P.C.; de Moraes Gonçalves, J.L.; Sparovek, G. Köppen's climate classification map for Brazil. Meteorol. Z. 2013, 7, 711-728. [CrossRef]

17. Antunes Júnior, E.D.J.; Alves Júnior, J.; Casaroli, D. Calibração do sensor capacitivo ec-5 em um latossolo em função da densidade do solo. Rev. Eng. Agric. 2018, 26, 80-88. [CrossRef]

18. Reis, L.S.; Azevedo CAV de Albuquerque, A.W.; SJunior, J.F. Índice de área foliar e produtividade do tomate sob condições de ambiente protegido. Rev. Bras. Eng. Agrícola E Ambient. 2013, 17, 386-391. [CrossRef]

19. Llanderal, A.; García-Caparrós, P.; Segura, M.L.; Contreras, J.I.; Lao, M.T. Nutritional changes in petiole sap over space and time in a tomato crop greenhouse. J. Plant Nutr. 2019, 42, 1205-1217. [CrossRef]

20. Alves, B.J.R.; Smith, K.A.; Flores, R.A.; Cardoso, A.S.; Oliveira, W.R.D.; Jantalia, C.P.; Urquiaga, S.; Boddey, R.M. Selection of the most suitable sampling time for static chambers for the estimation of daily mean $\mathrm{N}_{2} \mathrm{O}$ flux from soils. Soil Biol. Biochem. 2012, 46, 129-135. [CrossRef]

21. Liu, P.; Yin, L.; Wang, S.; Zhang, M.; Deng, X.; Zhang, S.; Tanaka, K. Enhanced root hydraulic conductance by aquaporin regulation accounts for silicon alleviated salt-induced osmotic stress in Sorghum bicolor L. Environ. Exp. Bot. 2015, 111, 42-51. [CrossRef]

22. Wang, Y.; Zhang, B.; Jiang, D.; Chen, G. Silicon improves photosynthetic performance by optimizing thylakoid membrane protein components in rice under drought stress. Environ. Exp. Bot. 2019, 158, 117-124. [CrossRef]

23. Cao, B.; Ma, Q.; Zhao, Q.; Wang, L.; Xu, K. Effects of silicon on absorbed light allocation, antioxidant enzymes and ultrastructure of chloroplasts in tomato leaves under simulated drought stress. Sci. Hortic. 2015, 194, 53-62. [CrossRef]

24. Mittal, S.; Kumari, N.; Sharma, V. Differential response of salt stress on Brassica juncea: Photosynthetic performance, pigment, proline, D1 and antioxidant enzymes. Plant Physiol. Biochem. 2012, 54, 17-26. [CrossRef]

25. Rizwan, M.; Ali, S.; Ibrahim, M.; Farid, M.; Adrees, M.; Bharwana, S.A.; Zia-ur-Rehman, M.; Qayyum, M.F.; Abbas, F. Mechanisms of silicon-mediated alleviation of drought and salt stress in plants: A review. Environ. Sci. Pollut. Res. 2015, 22, 15416-15431. [CrossRef]

26. Bartlett, M.K.; Klein, T.; Jansen, S.; Choat, B.; Sack, L. The correlations and sequence of plant stomatal, hydraulic, and wilting responses to drought. Proc. Natl. Acad. Sci. USA 2016, 113, 13098-13103. [CrossRef] 
27. Gao, X.; Zou, C.; Wang, L.; Zhang, F. Silicon Decreases Transpiration Rate and Conductance from Stomata of Maize Plants. J. Plant Nutr. 2006, 29, 1637-1647. [CrossRef]

28. Sangster, A.G.; Hodson, M.J.; Tubb, H.J. Chapter 5 Silicon deposition in higher plants. In Studies in Plant Science, Silicon in Agriculture; Datnoff, L.E., Snyder, G.H., Korndörfer, G.H., Eds.; Elsevier: Amsterdam, The Netherlands, 2001; pp. 85-113. [CrossRef]

29. Bosnic, P.; Bosnic, D.; Jasnic, J.; Nikolic, M. Silicon mediates sodium transport and partitioning in maize under moderate salt stress. Environ. Exp. Bot. 2018, 155, 681-687. [CrossRef]

30. Maillard, A.; Ali, N.; Schwarzenberg, A.; Jamois, F.; Yvin, J.-C.; Hosseini, S.A. Silicon transcriptionally regulates sulfur and ABA metabolism and delays leaf senescence in barley under combined sulfur deficiency and osmotic stress. Environ. Exp. Bot. 2018, 155, 394-410. [CrossRef]

31. Biswal, A.K.; Pattanayak, G.K.; Pandey, S.S.; Leelavathi, S.; Reddy, V.S.; Govindjee Tripathy, B.C. Light Intensity-Dependent Modulation of Chlorophyll b Biosynthesis and Photosynthesis by Overexpression of Chlorophyllide a Oxygenase in Tobacco. Plant Physiol. 2012, 159, 433-449. [CrossRef]

32. Chen, W.; Yao, X.; Cai, K.; Chen, J. Silicon Alleviates Drought Stress of Rice Plants by Improving Plant Water Status, Photosynthesis and Mineral Nutrient Absorption. Biol. Trace Elem. Res. 2011, 142, 67-76. [CrossRef] [PubMed]

33. Teixeira, G.C.M.; de Mello Prado, R.; Rocha, A.M.S.; dos Santos, L.C.N.; dos Santos Sarah, M.M.; Gratão, P.L.; Fernandes, C. Silicon in Pre-sprouted Sugarcane Seedlings Mitigates the Effects of Water Deficit After Transplanting. J. Soil Sci. Plant. Nutr. 2020. [CrossRef]

34. Zhu, Y.; Gong, H. Beneficial effects of silicon on salt and drought tolerance in plants. Agron. Sustain. Dev. 2014, 34, 455-472. [CrossRef]

35. Sistani, K.R.; Savant, N.K.; Reddy, K.C. Effect of rice hull ash silicon on rice seedling growth. J. Plant Nutr. 1997, 20, 195-201. [CrossRef]

36. Sitko, K.; Gieroń, Ż; Szopiński, M.; Zieleźnik-Rusinowska, P.; Rusinowski, S.; Pogrzeba, M.; Daszkowska-Golec, A.; Kalaji, H.M.; Małkowski, E. Influence of short-term macronutrient deprivation in maize on photosynthetic characteristics, transpiration and pigment content. Sci. Rep. 2019, 9, 1-12. [CrossRef]

37. Liang, Y.; Zhang, W.; Chen, Q.; Liu, Y.; Ding, R. Effect of exogenous silicon (Si) on H+-ATPase activity, phospholipids and fluidity of plasma membrane in leaves of salt-stressed barley (Hordeum vulgare L.). Environ. Exp. Bot. 2006, 57, 212-219. [CrossRef]

38. Gong, H.; Chen, K. The regulatory role of silicon on water relations, photosynthetic gas exchange, and carboxylation activities of wheat leaves in field drought conditions. Acta Physiol. Plant. 2012, 34, 1589-1594. [CrossRef]

39. Liang, Y.; Zhu, J.; Li, Z.; Chu, G.; Ding, Y.; Zhang, J.; Sun, W. Role of silicon in enhancing resistance to freezing stress in two contrasting winter wheat cultivars. Environ. Exp. Bot. 2008, 64, 286-294. [CrossRef]

40. Sonobe, K.; Hattori, T.; An, P.; Tsuji, W.; Eneji, A.E.; Kobayashi, S.; Kawamura, Y.; Tanaka, K.; Inanaga, S. Effect of Silicon Application on Sorghum Root Responses to Water Stress. J. Plant Nutr. 2010, 34, 71-82. [CrossRef]

41. Per, T.S.; Khan, N.A.; Reddy, P.S.; Masood, A.; Hasanuzzaman, M.; Khan, M.I.R.; Anjum, N.A. Approaches in modulating proline metabolism in plants for salt and drought stress tolerance: Phytohormones, mineral nutrients and transgenics. Plant Physiol. Biochem. 2017, 115, 126-140. [CrossRef]

42. Pei, Z.F.; Ming, D.F.; Liu, D.; Wan, G.L.; Geng, X.X.; Gong, H.J.; Zhou, W.J. Silicon Improves the Tolerance to Water-Deficit Stress Induced by Polyethylene Glycol in Wheat (Triticum aestivum L.) Seedlings. J. Plant Growth Regul. 2010, 29, 106-115. [CrossRef]

43. Cao, B.; Ma, Q.; Xu, K. Silicon restrains drought-induced ROS accumulation by promoting energy dissipation in leaves of tomato. Protoplasma 2020, 257, 537-547. [CrossRef]

44. Silva, O.N.; Lobato, A.K.S.; Ávila, F.W.; Costa, R.C.L.; Neto, C.F.O.; Filho, B.G.S.; Filho, A.P.M.; Lemos, R.P.; Pinho, J.M.; Medeiros, M.B.C.L.; et al. Silicon-induced increase in chlorophyll is modulated by the leaf water potential in two water-deficient tomato cultivars. Plant Soil Environ. 2012, 58, 481-486. [CrossRef]

45. Martinez, V.; Nieves-Cordones, M.; Lopez-Delacalle, M.; Rodenas, R.; Mestre, T.C.; Garcia-Sanchez, F.; Rubio, F.; Nortes, P.A.; Mittler, R.; Rivero, R.M. Tolerance to Stress Combination in Tomato Plants: New Insights in the Protective Role of Melatonin. Molecules 2018, 23, 535. [CrossRef] 
46. Reddy, A.R.; Chaitanya, K.V.; Vivekanandan, M. Drought-induced responses of photosynthesis and antioxidant metabolism in higher plants. J. Plant Physiol. 2004, 161, 1189-1202. [CrossRef] [PubMed]

47. Shi, Y.; Zhang, Y.; Han, W.; Feng, R.; Hu, Y.; Guo, J.; Gong, H. Silicon Enhances Water Stress Tolerance by Improving Root Hydraulic Conductance in Solanum lycopersicum L. Front. Plant Sci. 2016, 7, 196. [CrossRef]

48. Zhang, Y.; Shi, Y.; Gong, H.; Zhao, H.; Li, H.; Hu, Y.; Wang, Y. Beneficial effects of silicon on photosynthesis of tomato seedlings under water stress. J. Integr. Agric. 2018, 17, 2151-2159. [CrossRef]

Publisher's Note: MDPI stays neutral with regard to jurisdictional claims in published maps and institutional affiliations.

(C) 2020 by the authors. Licensee MDPI, Basel, Switzerland. This article is an open access article distributed under the terms and conditions of the Creative Commons Attribution (CC BY) license (http://creativecommons.org/licenses/by/4.0/). 